\title{
Impact of an Integrated Yoga Therapy Protocol on Insulin Resistance and Glycemic Control in Patients with Type 2 Diabetes Mellitus
}

\author{
Manoharan Mangala Gowri, M.Sc., (Ph.D). ${ }^{1}$, Jayanthi Rajendran, Ph.D. ${ }^{1}$, Abu \\ Raghavan Srinivasan, Ph.D., F.I.M.S.A. ${ }^{*}$, Ananda Balayogi Bhavanani, M.D., \\ D.Sc. (Yoga) ${ }^{2}$, and Ramanathan Meena, Ph.D. ${ }^{2}$ \\ ${ }^{\prime}$ Department of Biochemistry, Mahatma Gandhi Medical College \& Research Institute, Sri Balaji \\ Vidyapeeth $(S B V)$, SBV Campus, Pillaiyarkuppam, Pondicherry, India; and ${ }^{2}$ Centre for Yoga Therapy \\ Education and Research, Sri Balaji Vidyapeeth (SBV), SBV Campus, Pillaiyarkuppam, Pondicherry, \\ India
}

\begin{abstract}
Objective: Diabetes mellitus (DM), characterized by chronic hyperglycemia, is attributed to relative insulin deficiency or resistance, or both. Studies have shown that yoga can modulate parameters of insulin resistance. The present study explored the possible beneficial effects of integrated yoga therapy with
\end{abstract}

Abbreviations: BMI, body mass index; DM, diabetes mellitus; FBG, fasting blood glucose; HbA1c, hemoblobin A1c; HDL, high-density lipoprotein; HOMA-IR, homeostatic model assessment for insulin resistance; IR, insulin resistance; PPBG, post-prandial blood glucose; QC, quality control; SBV, Sri Balaji Vidyapeeth; T2D, type 2 diabetes mellitus; WHO, World Health Organization.

Citation: Mangala Gowri VV, Jayanthi R, Srinivasan AR, Bhavanani AB, Meena R. Impact of an Integrated Yoga Therapy Protocol on Insulin Resistance and Glycemic Control in Patients with Type 2 Diabetes Mellitus. Rambam Maimonides Med J 2022;13 (1):eo005. DOI: 10.5041/RMMJ.10462

Copyright: (C) 2022 Mangala Gowri et al. This is an open-access article. All its content, except where otherwise noted, is distributed under the terms of the Creative Commons Attribution License (http://creativecommons.org/licenses/by/3.0), which permits unrestricted use, distribution, and reproduction in any medium, provided the original work is properly cited.

Acknowledgement: The authors wish to place on record their sincere thanks to Professor S.C. Parija, Honorable ViceChancellor, Sri Balaji Vidyapeeth; Professor C. Adithan, Dean-Research; and Professor S. Sumathi, Head of the Department of Biochemistry for their interest in facilitating this study.

Conflict of interest: No potential conflict of interest relevant to this article was reported.

* To whom correspondence should be addressed. E-mail: raghavan.drvars20oo@gmail.com 
reference to glycemic control and insulin resistance (IR) in individuals with diabetes maintained on standard oral medical care with yoga therapy, compared to those on standard oral medical care alone.

Methods: In this study, the subjects on yoga intervention comprised 35 type 2 diabetics, and an equal number of volunteers constituted the control group. Subjects ranged in age from 30 to 70 years, with hemoglobin A1c (HbA1c) test more than 7\%, and were maintained on diabetic diet and oral hypoglycemic agents. Blood samples were drawn prior to and after 120 days of integrated yoga therapy intervention. Fasting blood glucose (FBG), post-prandial blood glucose (PPBG), HbA1c, insulin, and lipid profile were assessed in both the intervention and control groups.

Results: The intervention group revealed significant improvements in body mass index (BMI) $\left(0.7 \mathrm{~kg} / \mathrm{m}^{2}\right.$ median decrease; $P=0.001$ ), FBG (20 mg/dL median decrease; $P<0.001)$, PPBG $(33 \mathrm{mg} / \mathrm{dL}$ median decrease; $P<0.001)$, HbA1c (0.4\% median decrease; $P<0.001)$, homeostatic model assessment for insulin resistance (HOMA-IR) (1.2 median decrease; $P<0.001$ ), cholesterol (13 mg/dL median decrease, $P=0.006)$, triacylglycerol (22 mg/dL median decrease; $P=0.027$ ), low-density lipoprotein (6 mg/dL median decrease; $P=0.004$ ), and very-low-density lipoprotein levels ( $4 \mathrm{mg} / \mathrm{dL}$ median decrease; $P=0.032$ ). Increases in highdensity lipoprotein after 120 days were not significant $(6 \mathrm{mg} / \mathrm{dL}$ median increase; $P=0.15)$. However, when compared to changes observed in patients in the control group, all these improvements proved to be significant.

Conclusion: Administration of integrated yoga therapy to individuals with diabetes leads to a significant improvement in glycemic control, insulin resistance, and key biochemical parameters.

KEY WORDS: DM, dyslipidemia, HOMA-IR, yoga therapy

\section{INTRODUCTION}

Diabetes mellitus (DM) is a leading cause of mortality worldwide. As per 2019 estimates, 77 million individuals had diabetes in India. The figures are expected to touch a staggering 134 million by the year $2045 .^{1}$

Yoga has its roots firmly entrenched in India and evolved over the last 4,000 years as a traditional form of mind-body training. Yoga asanas (typical postures) and pranayama (breath control) have recently become very popular, and the role of yoga in several chronic diseases has become the topic of current interest. $^{2-4}$

A host of evidence-based trials has shown that yoga can pronouncedly attenuate fasting blood glucose and improve glycemic control, besides improving the lipid levels and quality of life in diabetic paients. ${ }^{-12}$ Mind-body practices essentially depend on the ability of the mind to enhance physical health (and vice versa). In recent years, the practice of yoga as a viable non-invasive approach has been steadily rising, thanks to evidence-based reports. ${ }^{13-15}$ It must be stressed that yoga is generally safe and simple to learn and could be practiced by individuals who are interested in yoga learning. ${ }^{16-19}$ Furthermore, yoga paves the way for nodal strategies to combat stress, reduce anxiety, and enhance positive emotions. ${ }^{20}$
Several earlier findings indicate that yogic practices may lead to pronounced improvements in DM management. The significance of non-drug lifestyle modification could hold the all-important and decisive key to diabetic management. In this context there is a need to educate patients and their families on the benefits of evidence-based yoga therapy. ${ }^{21,22}$ The main objective of this study was to evaluate the added value of an integrated yoga therapy protocol in improving fasting blood glucose (FBG), postprandial blood glucose (PPBG), hemoglobin A1c (HbA1c), insulin, and lipid profile in type 2 diabetic patients treated with oral hypoglycemics.

\section{METHODS}

\section{Setting}

This study was carried out over two years (20182020) by the Department of Biochemistry, the Diabetic Outpatient Clinic, and the Yoga Therapy Centre of Mahatma Gandhi Medical College and Research Institute, Sri Balaji Vidyapeeth (SBV), Puducherry, India, a tertiary care teaching hospital. The study was approved by the institutional research advisory committee and the institutional ethics committee (vide project no. Ph.D. Project/2017/05/04 dt. 4/ 5/2017). All subjects recruited to this study signed an informed consent. 


\section{Study Population}

The eligibility assessment was carried out on 159 subjects of both sexes who had visited our diabetic clinics. Among them, 50 patients were excluded since they did not meet the inclusion criteria or had declined to participate for personal reasons. Based on randomization 59 patients were assigned to yoga intervention and 50 served as the controls. Thirtyeight members of the intervention group completed 10 sessions of integrated yoga therapy; 21 were unable to meet the compliance requirements. Of those who had completed ten sessions ( $n=38)$, 2 were lost at follow-up and 1 relocated due to new employment; these 3 participants were deemed as discontinued. In the control group ( $n=50), 8$ were lost during follow-up. Of the remaining 42, 35 were taken to facilitate an exact match in numbers with reference to the yoga group subjects. The sexes of the members of both groups were also noted (yoga intervention: females, $n=21$, males, $n=14$; control: females, $n=12$, males, $n=23$ ).

The final study group included males and females between 30 and 70 years of age. Care was taken to include only those with a type $2 \mathrm{DM}$ (T2D) disease duration of a minimum of three years and HbA1c more than 7\%. All had to be on a diabetic diet, and maintained on medical oral hypoglycemic agents. Potential recruits had to agree to participate in a randomized study in which only some of the study subjects would be asked to participate in yoga therapy sessions.

Potential recruits were excluded if they had type $1 \mathrm{DM}$ or conditions associated with insulin resistance, such as pregnancy or nursing, or were smokers, tobacco chewers, and alcohol consumers. Subjects who had expressed inability to perform the yoga techniques as given in the protocol were also promptly excluded from the study.

\section{Randomization}

Using a computer-generated random allocation sequence, study participants were assigned to one of two groups. Both groups were treated by conventional treatment for T2D: diabetic diet and medical oral hypoglycemic drugs. Patients in Group I (study group) were treated by the conventional treatment for T2D as described above, and were also asked to participate in an integrated yoga therapy intervention. Patients in Group II served as controls.

\section{Study Intervention}

Intervention consisted of 10 sessions essentially based on twice weekly yoga therapy taught initially in a graded manner. Patients in Group I were also asked to practice at home twice weekly, to maintain the regularity, rhythm, and repetition that are essential to the practice. Otherwise, the study subjects in both Group I and Group II were advised to maintain their regimen of oral hypoglycemic agents. Regular phone calls were made by the principal investigator of the study to subjects in order to facilitate compliance in toto. The study subjects as well as the controls were advised to return to the outpatient department following a period of 120 days.

Baseline investigations were performed and blood samples obtained after 120 days. Proper advice regarding diet and lifestyle modification was duly provided. Both groups were advised to take fiber-rich foods such as leafy green vegetables. The yoga-based intervention protocol is detailed in Table 1, with suggested benefits for each posture.

\section{Evaluation of Endpoints}

Anthropometric measurements were taken in association with baseline biochemical parameters. The anthropometric measurements and biochemical parameters were also measured after 120 days. Detailed methodology of the study is given in the CONSORT diagram (Figure 1). The fasting or postabsorptive blood sample (12-h) was obtained through a venipuncture in the arm with the individual maintained in an upright position and following 5 minutes in the resting state. All participants were asked to provide one more blood sample to facilitate the quantitation of post-prandial blood glucose, 2 hours after a meal.

Various biochemical parameters were evaluated at baseline and after 120 days for all participants of both groups, including fasting and PPBG, plasma insulin, and lipid profile. Biochemical measurements were based on established laboratory procedures in compliance with the guidelines of the International Federation of Clinical Chemistry and Laboratory Medicine (IFCC).

Fasting and PPBG levels were estimated according to the enzymatic (glucose oxidase-peroxidase) method. Fasting insulin (venous plasma) was estimated by automated electrochemiluminescence. Gly- 
Table 1. Yoga Therapy Protocol for Individuals with Type 2 Diabetes Mellitus (DM). ${ }^{23}$

\begin{tabular}{|c|c|c|}
\hline Yoga Therapy & Duration & Benefits \\
\hline Jathis (warming up) & $5 \mathrm{~min}$ & $\begin{array}{l}\text { Helps loosen the joints and prepares the body for } \\
\text { performing asanas }\end{array}$ \\
\hline Standing postures & \multicolumn{2}{|l|}{ Total $10 \mathrm{~min}$} \\
\hline Palm tree posture: Talasana & \multirow{4}{*}{$\begin{array}{l}20 \text { sec each } \\
\text { side/asanas/ } \\
3 \text { sets }\end{array}$} & Stretches and tones up all back and leg muscles \\
\hline Triangle posture: Trikonasana & & Relieves upper and lower extremities stiffness \\
\hline $\begin{array}{l}\text { Extended side angle posture: } \\
\text { Parsvakonasana }\end{array}$ & & \multirow{2}{*}{$\begin{array}{l}\text { Helps reduce the fat accumulation around the } \\
\text { waist and hip regions, which helps in insulin } \\
\text { sensitivity by ameliorating insulin resistance }\end{array}$} \\
\hline Hero pose: Veerasana & & \\
\hline Sitting postures & $\begin{array}{l}\text { Total } 7 \text { min for all } \\
\text { sitting asanas }\end{array}$ & \\
\hline \multirow{2}{*}{$\begin{array}{l}\text { Wind-relieving pose: } \\
\text { Pavanamukthasana }\end{array}$} & \multirow[t]{2}{*}{$10 \mathrm{sec} / 5$ rounds } & Enhances digestion and elimination of waste \\
\hline & & $\begin{array}{l}\text { Helps reduce fat accumulation around the } \\
\text { abdomen, waist, and hip regions, thus reshaping } \\
\text { the body structure }\end{array}$ \\
\hline \multirow[t]{5}{*}{$\begin{array}{l}\text { Compact pose drawing everything } \\
\text { to one's center: Navasana }\end{array}$} & \multirow[t]{5}{*}{$10 \mathrm{sec} / 5$ rounds } & $\begin{array}{l}\text { Tones up abdominal and thigh muscles in a healthy } \\
\text { manner }\end{array}$ \\
\hline & & $\begin{array}{l}\text { Sends a pronounced blood supply to the pelvic area } \\
\text { by creating healthy tension }\end{array}$ \\
\hline & & $\begin{array}{l}\text { Effective for disorders of the intestines, pancreas, } \\
\text { liver, gall bladder, and spleen }\end{array}$ \\
\hline & & $\begin{array}{l}\text { Stretches and tones up all of the back, arm, and } \\
\text { leg muscles }\end{array}$ \\
\hline & & $\begin{array}{l}\text { This posture gives an excellent massage to the } \\
\text { abdominal organs and is useful for DM patients }\end{array}$ \\
\hline Half spinal twist pose: Vakrasana & $\begin{array}{l}10 \mathrm{sec} / \text { each side } \\
/ 5 \text { rounds }\end{array}$ & $\begin{array}{l}\text { Helps reduce fat accumulation around the } \\
\text { abdomen, waist, and hip region, thus reshaping } \\
\text { body structure and helping to fight obesity; these } \\
\text { asanas also improve insulin sensitivity }\end{array}$ \\
\hline $\begin{array}{l}\text { Half Lord of the fishes pose: } \\
\text { Ardha matseyendrasana }\end{array}$ & $\begin{array}{l}10 \mathrm{sec} / \text { each side } \\
/ 5 \text { rounds }\end{array}$ & $\begin{array}{l}\text { Helps correct structural deformities of the spine, } \\
\text { shoulder, and upper back regions }\end{array}$ \\
\hline \multirow{3}{*}{$\begin{array}{l}\text { Mudras (gestures) } \\
\text { Topsy-turvy gesture: } \\
\text { Viparitakarani* }\end{array}$} & \multirow{3}{*}{$\begin{array}{l}30 \mathrm{sec} / \\
30 \mathrm{sec} \text { relaxation }\end{array}$} & \multirow{2}{*}{$\begin{array}{l}\text { Promotes healthy metabolic function by stimulating } \\
\text { the pancreas and insulin uptake by the insulin- } \\
\text { sensitive body cells (i.e. adipose tissue, heart } \\
\text { muscle, and skeletal muscle) }\end{array}$} \\
\hline & & \\
\hline & & $\begin{array}{l}\text { Highly recommended for control of blood sugar in } \\
\text { DM and corrects thyroid imbalance }\end{array}$ \\
\hline $\begin{array}{l}\text { Pranayama (breathing techniques } \\
\text { in the sitting posture) }\end{array}$ & \multirow[t]{3}{*}{ Total $20 \mathrm{~min}$} & $\begin{array}{l}\text { Tones up cardio-respiratory function that may be } \\
\text { compromised in DM }\end{array}$ \\
\hline $\begin{array}{l}\text { Moon breathing (left side nostril } \\
\text { breathing): Chandra nadi }\end{array}$ & & \multirow{2}{*}{$\begin{array}{l}\text { Practicing 3-9 rounds daily helps relax the body- } \\
\text { emotion-mind complex; this complex enhances } \\
\text { insulin sensitivity and decreases insulin sensitivity }\end{array}$} \\
\hline Primordial chant: Pranava & & \\
\hline
\end{tabular}

Skull shining breathing

technique: Kapalbhati

Continued on next page. 
Table 1. Continued

\begin{tabular}{|c|c|c|}
\hline Yoga Therapy & Duration & Benefits \\
\hline Meditation & Total $12 \mathrm{~min}$ & \\
\hline $\begin{array}{l}\text { Primordial chant with gesture: Om } \\
\text { japa with mudras }\end{array}$ & $5 \mathrm{~min}$ & $\begin{array}{l}\text { Relaxes the body-emotion-mind complex and } \\
\text { provides complete healing through the production } \\
\text { of healing vibrations at all levels of existence }\end{array}$ \\
\hline $\begin{array}{l}\text { Dynamic body relaxation: Kaya } \\
\text { kriya } \\
\text { Part by part body relaxation } \\
\text { technique: Marmanasthana kriya }\end{array}$ & $\begin{array}{l}6 \text { rounds } \\
8 \text { min }\end{array}$ & Mind and body relaxation \\
\hline $\begin{array}{l}\text { Relaxation } \\
\text { Corpse pose: Shavasana }\end{array}$ & $5 \mathrm{~min}$ & Mind and body relaxation \\
\hline Total & $60 \mathrm{~min}$ & \\
\hline
\end{tabular}

Jathi(s) are warming-up exercises; Asana(s) are characteristic body postures; Mudra(s) are symbolic gestures; Om japa signifies the chanting of sacred sound; Pranayama are breathing techniques.

*To be done with caution.

DM, diabetes mellitus; IR, insulin resistance; min, minute(s); sec, second(s).

cosylated hemoglobin (HbA1c) was determined by high-performance liquid chromatography. Insulin resistance was computed by the homeostatic model assessment computed using the established formula. ${ }^{24}$ Triacylglycerols and total serum cholesterol were quantitated by the enzymatic method. Highdensity lipoprotein (HDL) cholesterol was quantitated by polyanion precipitation. The LDL cholesterol was computed by the Friedewald equation. Care was taken with reference to the limitations of the Friedewald equation. All subjects underwent follow-up in order to ensure compliance.

The evaluation of biochemical parameters was based on stringent quality control (QC). Internal quality assessment was enabled with the assistance of QC samples provided by M/S Bio-Rad (Hercules, CA, USA). External quality assessment was initiated through a collaborative effort with the Clinical Biochemistry Laboratory (accredited by NABL under ISO/IEC 15189), Christian Medical College, Vellore, Tamilnadu, India which is under the aegis of the Association of Clinical Biochemists of India (ACBI).

\section{Statistical Analysis}

The JASP 0.8.5 software was employed in this study. Differences in baseline characteristics and baseline investigations were compared between Group I and Group II. Differences observed between baseline and 120 days were evaluated for each variable within each group. Finally, Group I and Group II were com- pared for changes observed between baseline and 120 days. Non-parametric tests were used throughout. A $P$ value of $<0.05$ was considered significant.

\section{RESULTS}

Table 2 presents the baseline characteristics and baseline investigations of both groups. Apart from differences in BMI and PPBG, no other differences were noted between the two groups. Table 3 presents the median and interquartile ranges for each variable in Group I and Group II at baseline and after 120 days. Patients treated with yoga demonstrated significant improvements in BMI, FBG, PPBG, HbA1c, HOMA-IR, cholesterol, TAG, LDL, and VLDL levels; increases in HDL after 120 days were not significant. However, when compared to patients in Group II, all these improvements proved to be significant.

\section{DISCUSSION}

Our study was based on a structured integrated yoga protocol (Talaasana, Trikonasana, Parsvakonasana, Veerasana, and Pavanamukthasana), and showed that participants had significant reduction in serum total cholesterol, TAG, and LDL cholesterol, as supported by another Indian study. Ardha matseyendrasana, vakrasana, and navasana stimulate the pancreas for insulin secretion. ${ }^{25}$

Yoga has been increasingly considered to be a promising, cost-effective, and non-invasive option in 


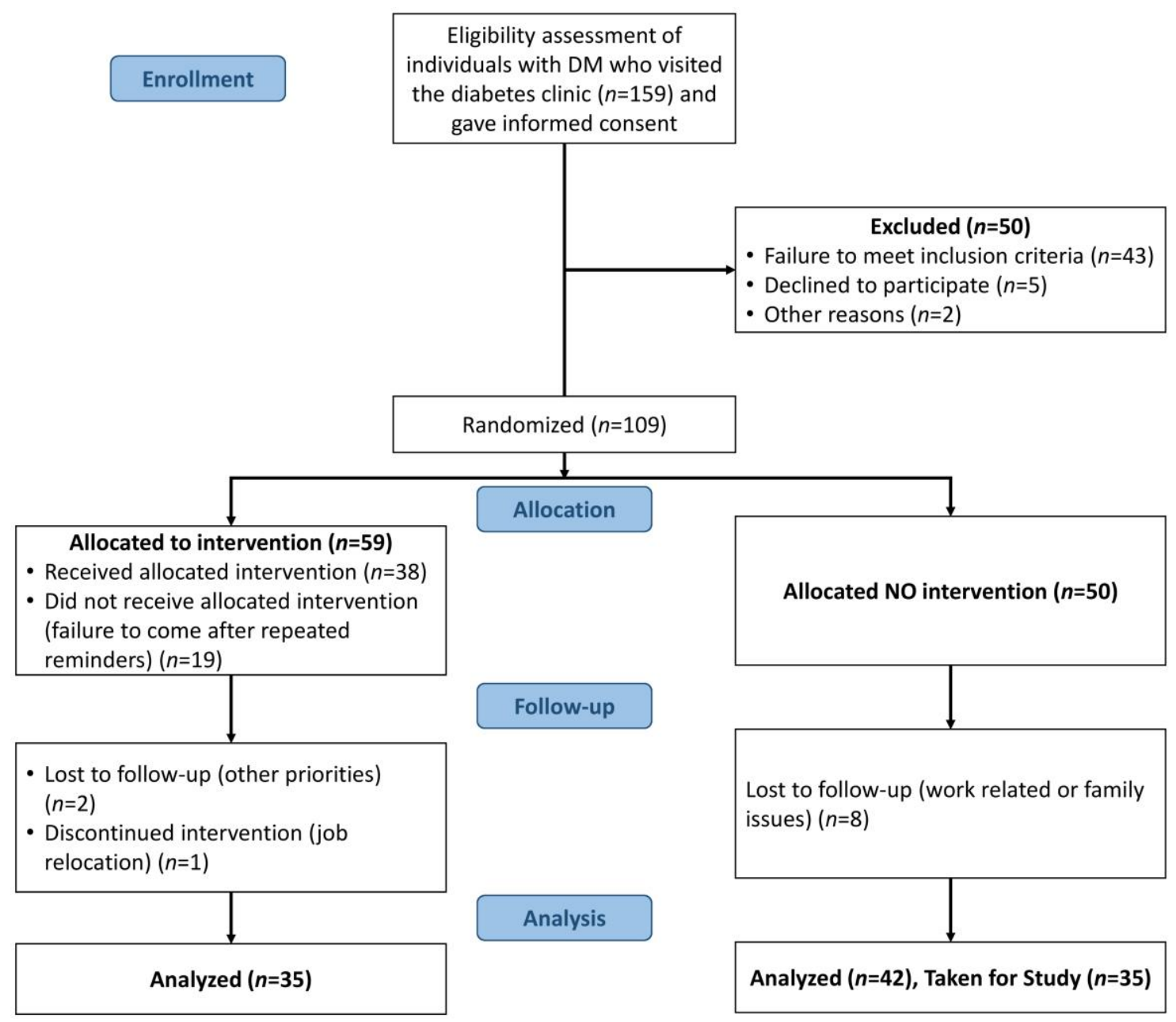

Figure 1. Study Methodology (CONSORT Flow Chart Diagram).

DM, diabetes mellitus.

the management of DM, with data from several studies implying that yoga and other mind-body therapeutic modalities could pronouncedly attenuate stress-related hyperglycemia and have a positive effect on blood glucose control. Stress management has become increasingly important in recent times and holds the key to the management of DM. It is believed that pranayama techniques and yoga therapy alleviate stress-induced hyperglycemia. The practice of chandra nadi pranayama, pranava pranayama, and dhayana as well as Om japa with mudras reduces stress and helps in proper metabolism. During periods of stress or trauma, the increased release of epinephrine in conjunction with glucagon leads to increased blood glucose. ${ }^{26,27}$ Kaya kriya and marmansthana kriya are relaxation techniques help to relax the mind and body.

\section{Mechanism}

Using controlled breathing techniques, meditation, and different body postures, yoga and other associated programs train the participants to invoke a relaxation response. This response enables the regulation of cortisol and other stress hormones that normally increase blood pressure and blood glucose levels. Enough evidence is available to state that insulin resistance plays a significant pathophysiologic role in DM, in addition to being a risk factor for the development of cardiovascular disease. ${ }^{28}$ The present study examined the effects of practicing a given protocol of 10 twice-weekly guided integrated yoga therapy sessions in individuals with DM over a period of four months' yoga. The emotional, psychological, physiological, and biochemical changes noted in these patients are outlined in Figure 2. The 
Table 2. Baseline Characteristics of the Yoga Group (Group I) and the Control Group (Group II).

\begin{tabular}{|lcccc|}
\hline Characteristic & $\begin{array}{c}\text { Group I } \\
\text { Median (IQR) }\end{array}$ & $\begin{array}{c}\text { Group II } \\
\text { Median }(\mathrm{IQR})\end{array}$ & P Value \\
\hline Age (years) & $54(45,58)$ & $52.5(46.8,58)$ & 0.76 \\
BMI $\left(\mathrm{kg} / \mathrm{m}^{2}\right)$ & $26.6(25.0,29.2)$ & $24.6(22.4,27.7)$ & 0.028 \\
FBG $(\mathrm{mg} / \mathrm{dL})$ & $146(120,220)$ & $171(138,207)$ & 0.33 \\
PPBG $(\mathrm{mg} / \mathrm{dL})$ & $250(193,295)$ & $293(232,349)$ & 0.034 \\
HbA1c $(\%)$ & $8.1(7.5,10.3)$ & $8.1(7.8,10.1)$ & 0.50 \\
Insulin $(\mu \mathrm{lU} / \mathrm{mL})$ & $13.8(7.2,19.7)$ & $13.2(6.6,22.7)$ & 0.88 \\
HOMA-IR* & $5.2(2.5,7.5)$ & $5.8(3.8,7.2)$ & 0.59 \\
Cholesterol $(\mathrm{mg} / \mathrm{dL})$ & $193(148,217)$ & $190(149,211)$ & 0.72 \\
TAG $(\mathrm{mg} / \mathrm{dL})$ & $114(80,157)$ & $114(97,173)$ & 0.82 \\
HDL $(\mathrm{mg} / \mathrm{dL})$ & $51(45,58)$ & $55(47,60)$ & 0.36 \\
LDL $(\mathrm{mg} / \mathrm{dL})$ & $116(80,145)$ & $108(77,131)$ & 0.36 \\
VLDL $(\mathrm{mg} / \mathrm{dL})$ & $23(16,31)$ & $23(19,35)$ & 0.84 \\
\hline
\end{tabular}

${ }^{*} \mathrm{HOMA}-\mathrm{IR}$ is a computed value and has no units.

BMI, body mass index; FBG, fasting blood glucose; HbA1c, glycosylated hemoglobin; HDL, high-density lipoprotein; HOMA-IR, homeostatic model assessment of insulin resistance ([glucose $(\mathrm{mmol} / \mathrm{L}) \times$ insulin $(\mu \mathrm{lU} / \mathrm{mL})]$ / 22.5); IQR, interquartile range; LDL, low-density lipoprotein; PPBG, postprandial blood glucose; TAG, triacylglycerol; VLDL, very-low-density lipoprotein.

practice of yoga in these patients resulted in a significant decrease in BMI, body weight, total cholesterol, triacylglycerol, and LDL cholesterol, and an increase in HDL. Earlier, studies had depicted that lifestyle modification and oral drugs could improve diabetic dyslipidemia. ${ }^{27}$ Moreover, insulin resistance (IR) is correlated with a decreased response to the metabolic actions of insulin, including insulinstimulated glucose disposal and inhibition of hepatic glucose output. The hepatic output of glucose, through gluconeogenesis, has been the subject of much research in recent years and is the favored target for oral hypoglycemic drugs in recent years. ${ }^{29}$ Our results suggest that, compared with controls, intervention through yoga could help improve insulin sensitivity in DM. It must, however, be noted that dynamic measures of insulin sensitivity resemble stimulated insulin action and denote the peripheral insulin-mediated glucose uptake. Existing studies have found positive effects from physical exercise and integrated yoga protocols. $3^{\circ}$ A structured yoga therapy protocol is an additional interventional strategy to improve glycemic control, which is presently recommended to reduce IR seen in DM. The BMI is correlated with IR, visceral fat, fasting blood sugar, and musculoskeletal mass among T2D patients with peripheral neuropathy. ${ }^{31}$

Yet another significant aspect is that oxidative stress is a fundamental problem of metabolic syndrome. Oxidative stress causes IR in the peripheral tissues by affecting various facets in insulin receptor signal transduction. This culminates in decreased expression of the GLUT4 transporter in the cellular membrane. We also believe that various yogic interventions may be directly beneficial in rejuvenating cells of the pancreas by attenuating oxidative stress. This could lead to an increase in utilization and metabolism of glucose in the peripheral tissues, liver, and adipose tissues. ${ }^{32}$

Enhanced blood supply to the organs holds the key. This is linked to insulin receptor expression in muscles, which in turn increases glucose uptake by muscles and thereby reduces blood sugar. 33 The im- 


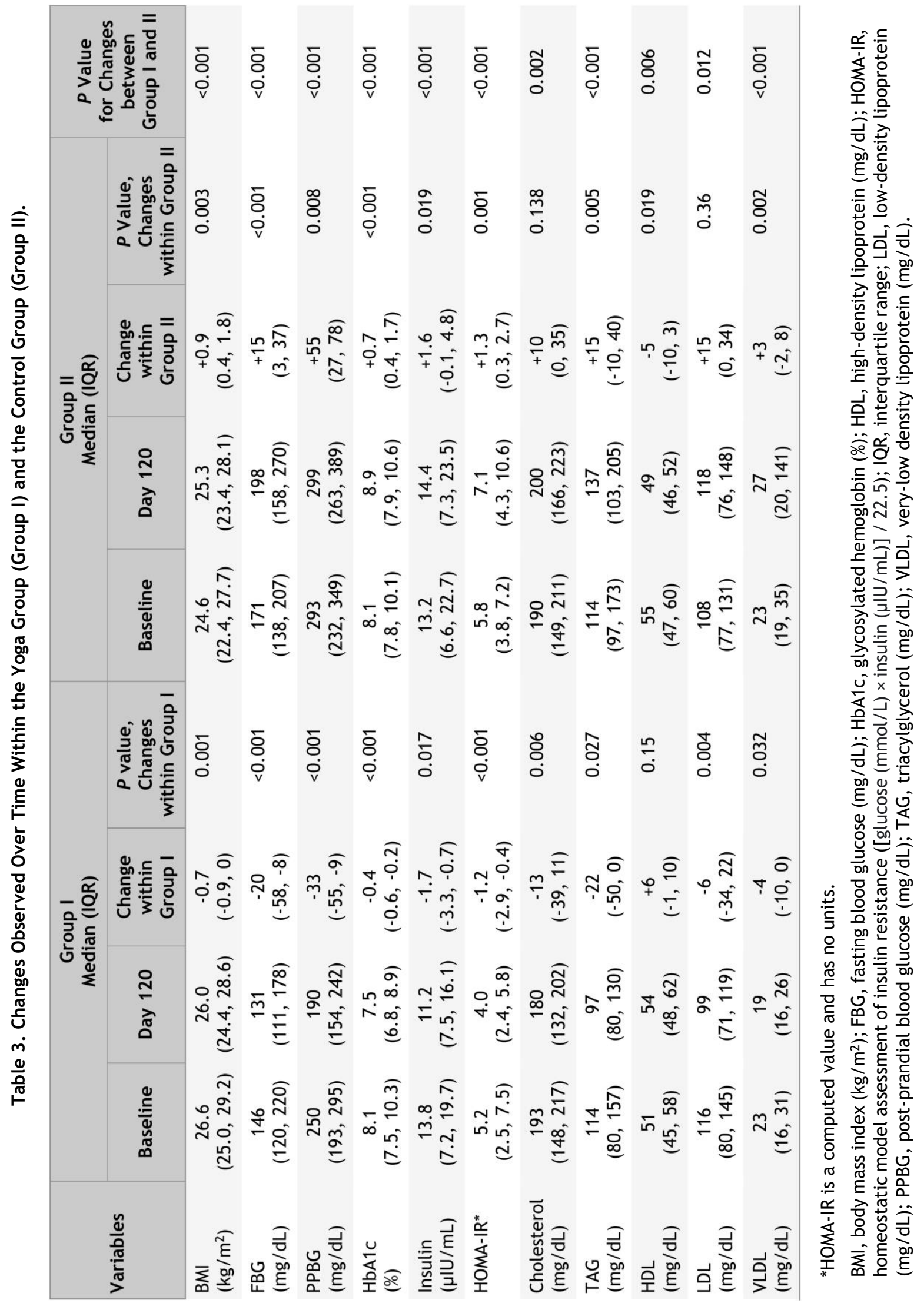




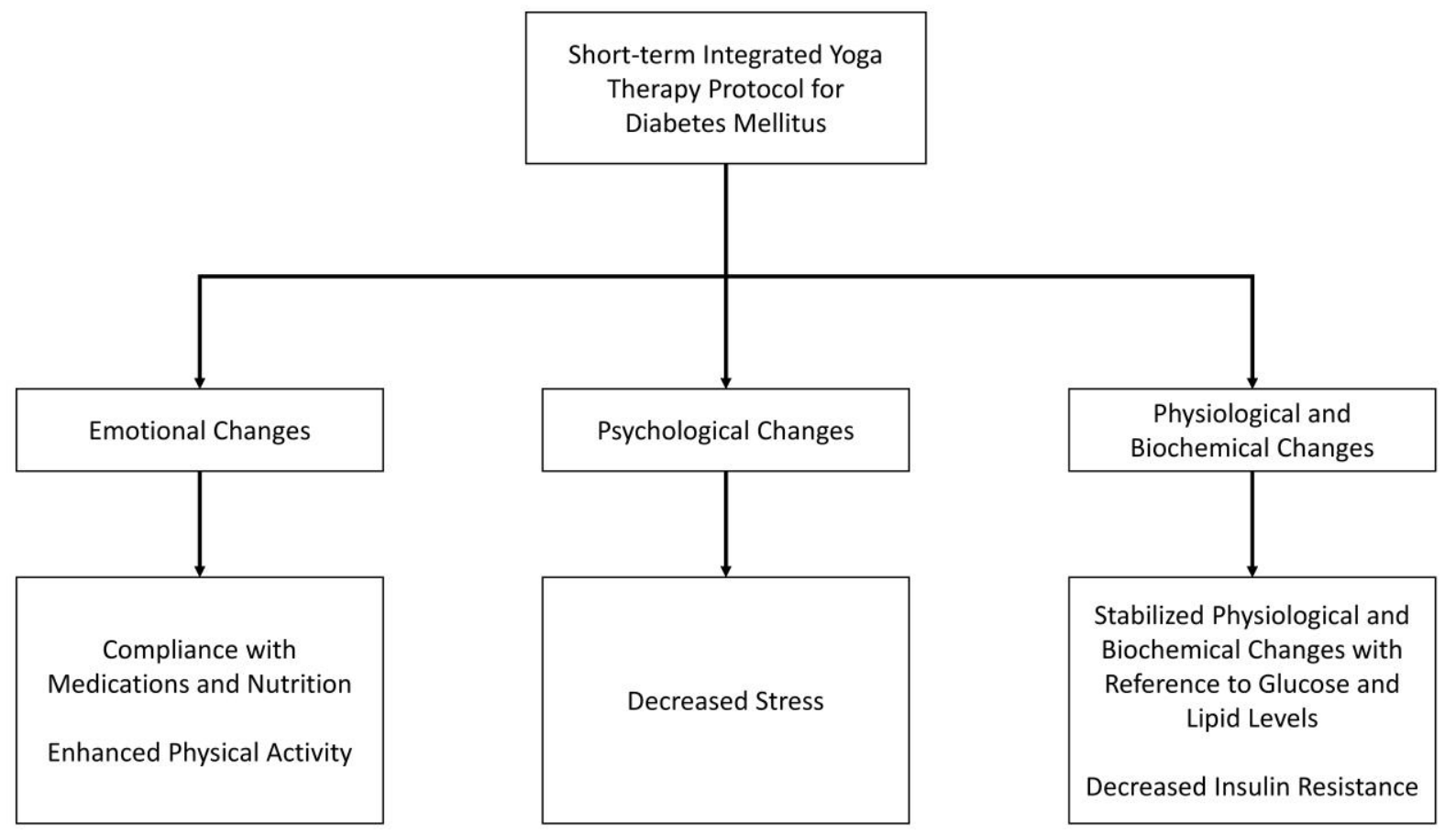

Figure 2. Positive Benefits of Integrated Yoga Therapy Achieved in Patient with Type 2 Diabetes (Group I).

provement in the lipid profile following yoga could be attributed to the increased activity of hepatic lipase and lipoprotein lipase at cellular level. This in turn increases uptake of TAG by adipose tissues. ${ }^{34}$ It is believed that yogic intervention could change the metabolic profile and effect elimination of stress, as stated by previous workers. 35,36

An earlier study has revealed that the practice of Raja yoga meditation could lower serum cholesterol.34 The beneficial effects of yoga in alleviating dyslipidemia have been investigated. 37,38

The beneficial effects of yoga as observed in this study are promising and hence in the long-term would bring proper control of blood sugar and stabilize lipid profile level. However, for various reasons, individuals with diabetes often cannot sustain the levels of recommended physical activity, and hence there is an inherent issue with compliance.

We do believe that the stretching of the body during yoga asanas could rejuvenate the islet cells, thus increasing insulin secretion and hence correcting the impaired insulin secretion in chronic diabetes. 33 However, we emphatically state that the protocol developed by us needs to be further taken up for future studies in a comprehensive manner to evaluate short- and long-term benefits of yoga on DM.

It is believed that the conglomerate of psychoneuro-endocrine and immune mechanisms has holistic effects on diabetes control. Earlier, studies had revealed that parasympathetic activation and the associated anti-stress mechanisms could help improve overall metabolic and psychological profiles, besides enhancing insulin sensitivity, and improving glucose tolerance and lipid metabolism. 39 We do believe that yoga therapy reduces blood glucose levels by enhancing insulin sensitivity and helps in the management of comorbid disease conditions associated with DM, thereby resulting in significantly improved clinical outcomes. The effect of physical exercise on blood lipid profile has been well documented. Physical activity and HDL appear to be linked through HDL's role in triglyceride metabolism..$^{\circ}$ Further studies are needed to investigate the LDL-lowering effect of yoga therapy. Our laboratory is presently pursuing research that includes the effect of yoga therapy in DM as evidenced by reliable markers of oxidative stress, anthropometry, and gene polymorphism of adiponectin, since oxidative stress and adiponectin levels are intrinsically linked 
to IR. We expect to receive the results of this new study in the coming months.

\section{Novelty}

Prescribed integrated yoga therapy protocol is simple to practice, requires little space, and can be practiced at one's own convenience in the comfort of the home, at least 2 hours after a full meal. As an adjuvant, non-invasive therapy could help individuals with DM to delay the occurrence of micro- and macro-vascular complications such as retinopathy, neuropathy, nephropathy, and ischemic heart disease.

\section{CONCLUSION}

The results of the present study are encouraging, and it is concluded that integrated yoga therapy as an adjuvant and non-invasive therapy is ideal for people with diabetes. The integrated yoga therapy protocol developed at our institute with a mild set of asanas and pranayama techniques could be practiced easily and could have beneficial effects in individuals with diabetes.

\section{Limitations}

Due to the small sample size a descriptive analysis was carried out. Age- and sex-matching were not possible. Direct homogeneous assay was not available for performing low-density lipoprotein estimation.

\section{Future Scope}

Yoga therapy is a non-invasive and viable lifestyle modification that may be practiced safely by people with diabetes. Yoga therapy, in association with standard/rational medication, could effectively delay the complications of DM. In the future, the effect of standardized yoga therapy should be considered in the light of gene polymorphisms associated with insulin sensitivity and insulin resistance, which would open newer vistas in personalized medicine. Yoga therapy thus could be considered as an effective therapeutic modality. More studies on yoga intervention in prediabetes, with inputs from lifestyle modifications, could open new horizons in noninvasive medicine based on complementary and adjuvant yoga therapy.

\section{REFERENCES}

1. Pradeepa R, Mohan V. Epidemiology of type 2 diabetes in India. Indian J Ophthalmol 2021;69:2932-8. CrossRef
2. Liu X-C, Pan L, Hu Q, Dong W-P, Yan J-H, Dong L. Effects of yoga training in patients with chronic obstructive pulmonary disease: a systematic review and meta-analysis. J Thorac Dis 2014;6:795-802. CrossRef

3. Ramachandran A, Snehalatha C, Shetty AS, Nanditha A. Trends in prevalence of diabetes in Asian countries. World J Diabetes 2012;3:110-17. CrossRef

4. Chandler K. The emerging field of yoga therapy. Hawaii Med J 2001;60:286-7. PMID: 11797492

5. Singh S, Kyizom T, Singh KP, Tandon OP, Madhu SV. Influence of pranayamas and yoga-asanas on serum insulin, blood glucose and lipid profile in type 2 diabetes. Indian J Clin Biochem 2008;23:365-8. CrossRef

6. Kyizom T, Singh S, Singh K, Tandon OP, Kumar R. Effect of pranayama \& yoga-asana on cognitive brain functions in type 2 diabetes- $\mathrm{P}_{3}$ event related evoked potential (ERP). Indian J Med Res 2010;131:636-40. PMID:20516534

7. Popli U, Subbe CP, Sunil K. Research letter-the role of yoga as a lifestyle modification in treatment of diabetes mellitus: results of a pilot study. Altern Ther Health Med 2014;20:24-6. PMID:25478800

8. Jyotsna VP, Dhawan A, Sreenivas V, Deepak KK, Singla R. Completion report: effect of comprehensive yogic breathing program on type 2 diabetes: a randomized control trial. Indian J Endocrinol Metab 2014;18:582-4. CrossRef

9. Skoro-Kondza L, Tai SS, Gadelrab R, Drincevic D, Greenhalgh T. Community based yoga classes for type 2 diabetes: an exploratory randomised controlled trial. BMC Health Serv Res 2009;9:33. CrossRef

10. Shantakumari N, Sequeira S, El deeb R. Effects of a yoga intervention on lipid profiles of diabetes patients with dyslipidemia. Indian Heart J2013;65:127-31. CrossRef

11. Gordon LA, Morrison EY, McGrowder DA, et al. Effect of exercise therapy on lipid profile and oxidative stress indicators in patients with type 2 diabetes. BMC Complement Altern Med 2008;8:21. CrossRef

12. Gordon L, Morrison EY, McGrowder DA, et al. Changes in clinical and metabolic parameters after exercise therapy in patients with type 2 diabetes. Arch Med Sci 2008;4:427-37.

13. Chappie CK. Modern yoga. Relig Stud Rev 2008; 34:71-6. $\underline{\text { CrossRef }}$

14. Raub JA. Psychophysiologic effects of Hatha yoga on musculoskeletal and cardiopulmonary function: a literature review. J Altern Complement Med 2002;8: 797-812. $\underline{\text { CrossRef }}$ 
15. Jeter PE, Slutsky J, Singh N, Khalsa SB. Yoga as a therapeutic intervention: a bibliometric analysis of published research studies from 1967 to 2013. J Altern Complement Med 2015;21:586-92. $\underline{\text { CrossRef }}$

16. Singh S, Malhotra V, Singh KP, Madhu SV, Tandon OP. Role of yoga in modifying certain cardiovascular functions in type 2 diabetic patients. J Assoc Physicians India 2004;52:203-6. PMID:15636309

17. Bernardi L, Sleight P, Bandinelli G, et al. Effect of rosary prayer and yoga mantras on autonomic cardiovascular rhythms: comparative study. BMJ 2001;323: 1446-9. $\underline{\text { CrossRef }}$

18. Carlson LE, Speca M, Faris P, Patel KD. One year prepost intervention follow-up of psychological, immune, endocrine and blood pressure outcomes of mindfulness-based stress reduction (MBSR) in breast and prostate cancer outpatients. Brain Behav Immun 2007;21:1038-49. CrossRef

19. Vaishali K, Kumar KV, Adhikari P, UnniKrishnan B. Effects of yoga-based program on glycosylated hemoglobin level serum lipid profile in community dwelling elderly subjects with chronic type 2 diabetes mellitus - a randomized controlled trial. Phys Occup Ther Geriatr 2012;30:22-30. CrossRef

20. Shohani M, Badfar G, Nasirkandy MP, et al. The effect of Yoga on stress, anxiety, and depression in women. Int J Prev Med 2018;9:21. CrossRef

21. Innes KE, Selfe TK. Yoga for adults with type 2 diabetes: a systematic review of controlled trials. J Diabetes Res 2016;2016:6979370. $\underline{\text { CrossRef }}$

22. Mitra A, Dewanjee D, Dey B. Mechanistic studies of lifestyle interventions in type 2 diabetes. World $\mathrm{J}$ Diabetes 2012;3:201-7. $\underline{\text { CrossRef }}$

23. Dayanidy YSG, Bhavanani AB. Yoga practical notes for yoga therapy courses at CYTER. Pondicherry: Center for Yoga Therapy Education and Research (CYTER); 2016:3-83. Available at: https://www. slideshare.net/anandabhavanani/cyter-yogapracticalbook (accessed January 9, 2022).

24. Jayanthi R, Srinivasan AR, Gopal N, Ramaswamy R. Association of divalent cations and insulin resistance with thyroid hormones in patients with type 2 diabetes mellitus. Diabetes Metab Syndr. 2017;11(Suppl 2):S885-90. CrossRef

25. Raveendran AV, Deshpandae A, Joshi SR. Therapeutic role of yoga in type 2 diabetes. Endocrinol Metab 2018;33:307-17. $\underline{\text { CrossRef }}$

26. Ranabir S, Reetu K. Stress and hormones. Indian J Endocrinol Metab 2011;15:18-22. $\underline{\text { CrossRef }}$

27. Burstein M, Scholnic HR, Morfin R. Rapid method for the isolation of lipoproteins from human serum with polyanions. J Lipid Res 1970;11:583-95. PMID: 4100998
28. Misra A, Alappan NK, Vikram NK, et al. Effect of supervised progressive resistance-exercise training protocol on insulin sensitivity, glycemia, lipids, and body composition in Asian Indians with type 2 diabetes. Diabetes Care 2008;31:1282-7. $\underline{\text { CrossRef }}$

29. Foretz M, Guigas B, Viollet B. Understanding the glucoregulatory mechanisms of metformin in type 2 diabetes mellitus. Nat Rev Endocrinol 2019;15:56989. $\underline{\text { CrossRef }}$

30. Chimkode SM, Kumaran SD, Kanhere VV, Shivanna R. Effect of yoga on blood glucose levels in patients with type 2 diabetes mellitus. J Clin Diagn Res 2015;9:CC01-3. CrossRef

31. Kumar AS, Maiya AG, Shastry BA, et al. Exercise and insulin resistance in type 2 diabetes mellitus: a systematic review and meta-analysis. Ann Phys Rehabil Med 2019;62:98-103. CrossRef

32. Ismail HM, Scapozza L, Ruegg UT, Dorchies OM. Diapocynin, a dimer of the NADPH oxidase inhibitor apocynin, reduces ROS production and prevents force loss in eccentrically contracting dystrophic muscle. PLoS One 2014;9:e110708. CrossRef

33. Manchnada SC, Narang R, Reddy KS, Sachdev V. Retardation of coronary atherosclerosis with yoga lifestyle intervention. J Assoc Physicians India 2000; 48:687-94. PMID:11273502

34. Vyas R, Dikshit N. Effect of meditation on respiratory system, cardiovascular system and lipid profile. Indian J Physio Pharmacol 2002;46:487-91. PMID: 12683226

35. Sahay BK. Role of yoga in diabetes. J Assoc Physicians India 2007;55:121-6. PMID:17571741

36. Bijlani RL, Vempati RP, Yadav RK, et al. A brief but comprehensive lifestyle education program based on yoga reduces risk factors for cardiovascular disease and diabetes mellitus. J Altern Complement Med 2005;11:267-74. $\underline{\text { CrossRef }}$

37. Thangasami SR, Chandani AL, Thangasami S. Emphasis of yoga in the management of diabetes. $\mathrm{J}$ Diabetes Metab 2015;6:61. $\underline{\text { CrossRef }}$

38. Mondal S, Kundu B, Saha S. Yoga as a therapeutic intervention for the management of type 2 diabetes mellitus. Int J Yoga 2018;11:129-38. $\underline{\text { CrossRef }}$

39. Asikainen T-M, Miilunpalo S, Kukkonen-Harjula K, et al. Walking trials in postmenopausal women: effect of low doses of exercise and exercise fractionization on coronary risk factors. Scand J Med Sci Sports 2003;13:284-92. CrossRef

40. Szapary PO, Bloedon LT, Foster GD. Physical activity and its effects on lipids. Curr Cardiol Rep 2003; 5:488-92. $\underline{\text { CrossRef }}$ 